\title{
Lateness Gene Concerning Photosensitivity Increases Yield, by Applying Low to High Levels of Fertilization, in Rice, a Preliminary Report
}

\author{
Masayuki Murai ${ }^{1 @}$, Birendra Bahadur Rana $^{2}$, Itsuro Takamure ${ }^{3}$, Haruki Nakazawa ${ }^{1}$, Mukunda \\ Bhattarai $^{2}$
}

${ }^{1}$ Faculty of Agriculture and Marine Science, Kochi University, 200 Otsu, Monobe, Nankoku, Kochi, Japan. @: muraim@kochi-u.ac.jp; ORCID: https://orcid.org/0000-0003-4832-5237; HN:<b104m102p@gmail.com ${ }^{2}$ United Graduate School of Agricultural Sciences, Ehime University, Matsuyama, Ehime, Japan; BBR: biru.deep25@gmail.com; MB:<mukundab_7@yahoo.com

${ }^{3}$ Research Faculty of Agriculture, Hokkaido University, Sapporo, Japan; takamure@abs.agr.hokudai.ac.jp

Received 07 Sept 2019, Revised 15 Jan 2020, Accepted 14 Feb 2020, Published 17 March 2020

Scientific Editors: Ujjawal Kr. S. Kushwaha, Jiban Shrestha, Bal K. Joshi Copyright (C) 2020 NARC. Permits unrestricted use, distribution and reproduction in any medium provided the original work is properly cited. The authors declare that there is no conflict of interest.

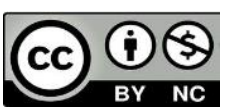

OPEN ACCESS

Creative Commons AttributionNonCommercial 4.0 International (CC BY-NC 4.0)

\section{ABSTRACT}

Various genes controlling heading time have been reported in rice. An isogenic-line pair of late and early lines "L" and "E" were developed from progenies of the $F_{1}$ of Suweon $258 \times$ an isogenic line of IR36 carrying Url gene. The lateness gene for photosensitivity that causes the difference between L and $\mathrm{E}$ was tentatively designated as "Ex(t)", although it's chromosomal location is unknown. The present study was conducted to examine the effects of $E x(\mathrm{t})$ on yield and related traits in a paddy field in two years. Chemical fertilizers containing $\mathrm{N}, \mathrm{P}_{2} \mathrm{O}_{5}$ and $\mathrm{K}_{2} \mathrm{O}$ were applied at the nitrogen levels of 4.00, 9.00 and $18.00 \mathrm{~g} / \mathrm{m}^{2}$ in total, being denoted by "N4", "N9" and "N18", respectively, in 2014. L was later in $80 \%$-heading by 18 or 19 days than E. Regarding total brown rice yield $\left(\mathrm{g} / \mathrm{m}^{2}\right), \mathrm{L}$ and $\mathrm{E}$ were 635 and 577, 606 and 548, and 590 and 501, respectively, at N18, N9 and N4, indicating that $E x(\mathrm{t})$ increased this trait by 10 to $18 \%$. Ex(t) increased yield of brown rice with thickness above $1.5 \mathrm{~mm}\left(\mathrm{~g} / \mathrm{m}^{2}\right)$, by 9 to $15 \%$. $E x(\mathrm{t})$ increased spikelet number per panicle by 16 to $22 \%$ and spikelet number per $\mathrm{m}^{2}$ by 11 to $18 \%$. Thousand-grain weight (g) was 2 to $4 \%$ lower in $\mathrm{L}$ than in $\mathrm{E}$. $\mathrm{L}$ was not significantly different from $\mathrm{E}$ in ripened-grain percentage. Hence, $E x(t)$ increased yield by increasing spikelet number per panicle. It is suggested that $E x(\mathrm{t})$ could be utilized to develop high yielding varieties for warmer districts of the temperate zone.

Keywords: Heading time, lateness gene, photosensitivity, yield, yield components. rice, breeding

\section{सारांश}

धानमा बाला निस्कने समय नियन्त्रय गर्ने विभिन्न जीनहरु पत्ता लगाइएका छन। सुवेवन २९८ र आइ आर ३६ को Url आइसोजेनिक लाइनको क्रसिड्गबाट एक जोडि ढिलो बाला निस्कने र छिटो बाला निस्कने आइसोजेनिक लाइन “एल" ₹ "इ" विकसति गरिएको थियो । ती दुइ आइसोजेनिक लाइनको बीचको बाला निस्कने अवधि एडटा प्रकाश संवेदनशील विलम्ब जीन $E x(t)$ ले नियन्त्रण गर्ने अनुमान गरिएको छ, यद्यपी यो जीनको क्रोमोजोमको स्थान अज्ञात छ। यस अध्ययनमा विलम्ब जीन $E x(t)$ ले धानबालीको उत्पादन तथा यससंग सम्बन्धित विशेषताहरुमा पार्ने असरको बारेमा विश्लेषण गर्नको लागि धानखेतमा परिक्षणहरु संचालन गरिएको थियो । नाइट्रोजन, फोस्फोरस र पोटासियम समाविष्ट रासायनिक मलहरु ४.००, ९.०० ₹ १८.०० ग्राम प्रतिमिटर नाइट्रोजन स्तरको रुपमा प्रयोग गरि क्रमशः "एन ४" , "एन ९" ₹ "एन १८" ले जनाइएको थियो । एल र इ को कुल खैरो चामल उत्पादन (ग्राम प्रतिमिटर) घ३५ र ९७७, ६०६ र ९४८, र ९९० र ९०१ क्रमशः एन ४, एन ९ र एन १८ मा भएको थियो, जसले विलम्ब जीन $E x(t)$ ले कुल खैरो चामल उत्पादन १० देखि १८\% बृद्धि भएको जनाउदछ। $E x(t)$ ले १.५ मिलिमिटर भन्दा बढी मोटाइ भएको खैरो चामलको उत्पादन (ग्राम प्रतिमिटर) $९$ देखि $९ ५ \%$ बृद्धि गरेको थियो । $E x(t)$ ले प्रतिबाला स्पाइकलेट संख्या र प्रतिमिटर स्पाइकलेट संख्या क्रमशः १६ देखि २२ ₹ ११ देखि १८\% बृद्धि गरेको थियो । $E x(t)$ ले एक हजार खैरो चामलको तौल (ग्राम) २ देखि $४ \%$ कम गरेको थियो । तर परिपक्क खैरो दानाको प्रतिशतमा $E x(t)$ को असर सांख्यिकीय रुपमा फरक पाइएको थिएन 
। अतः $E x(t)$ ले प्रतिबाला स्पाइकलेटको संख्या बृद्धि गरि धानको उत्पादन बृद्धि गरेको थियो । $E x(t)$ जीन समशितोष्ण क्षेत्रका गर्मी हावापानी भएका जिल्लाहरुमा धानको उत्पादन बृद्धि गर्नको लागि प्रयोग गर्न सकिन्छ।

\section{INTRODUCTION}

Growth duration is a major factor affecting regional adaptability and yield in rice (Oryza sativa L., $2 n=2 x=24)$. Longer growth duration allows rice plants to have sufficient vegetative growth to obtain higher biomass (Kawano and Tanaka 1968, Wada and Cruz 1989). In rice, growth duration is primarily determined by heading time. The duration from sowing to heading consists of the vegetative phase and panicle development phase. Vegetative phase is defined by the duration from sowing to the appearance of panicle primordium. Vegetative phase is further divided into basic vegetative phase and photoperiod sensitive phase (Chang et al 1969). Basic vegetative phase can be estimated by the minimum number of days from sowing to appearance of panicle primordium under the condition of short day-length and optimum temperature. Since the duration from appearance of panicle primordium to heading is about 30 days in rice varieties ordinarily (Akimoto and Togari 1939, Terao et al 1942, Saito et al 2007); length of vegetative phase can be approximated by number of days to heading.

In rice, more than 40 genes controlling heading time have been reported. Most of them control photosensitivity (Khun et al 2005, Ebana et al 2011). The major photosensitivity loci viz. Sel and El, located on chromosome 6 and chromosome 7, respectively, play important roles in determining heading time (Yokoo and Kikuchi 1977, Yokoo et al 1980, Yokoo and Kikuchi 1982; Okumoto et al 1991). The Sel locus involves at least three alleles, $\mathrm{Sel}-u, \mathrm{Se}$ - $n$ and Sel-e: the first two are incompletely dominant alleles controlling photosensitivity, while $\mathrm{Se} 1-e$ is a recessive allele with non-photosensitivity (Yokoo and Kikuchi 1977). Sel-e is distributed in rice varieties grown in Hokkaido prefecture and Tohoku district of Japan (Yokoo et al 1980, Ichitani et al 1997), while Sel- $n$ is harbored in middle and late heading varieties grown in warmer regions of Japan (Yokoo et al 1980). Se1-u is harbored in an indica variety 'Morak Sepilai' (Yokoo and Fujimaki 1971). Se1-u delays heading by at least 20 days as compared with its photo-insensitive allele $S e 1-e$. El-k allele at the El locus delays heading by about two weeks, as compared with its non-photosensitive allele $e 1$ (Ichitani et al 1998).

Murai developed an isogenic-line pair of late and early lines, denoted by "L" and "E", respectively, from descendants of the $\mathrm{F}_{1}$ from Suweon $258 \times$ an isogenic line of IR36 carrying Url gene. L was later in heading by 15 to 21 days than $\mathrm{E}$ (Trieu et al 2010). The difference in heading time between the two lines is controlled by a lateness gene (allele) tentatively designated as "Ex(t)". $E x(\mathrm{t})$ is an incompletely dominant allele controlling photosensitivity. Although the locus of $E x(\mathrm{t})$ is unknown, genetical analyses involving that by DNA markers suggest that it is different from either the Sel locus or the El locus (Murai unpublished).

Ghd7 allele at the $E 1$ locus delayed heading and had a pleiotropic effect of increasing spikelet number per panicle of main culm (Xue et al 2008, Saito et al 2011). However, any yield tests on field level regarding the effect of a lateness gene at $\mathrm{Sel}, \mathrm{El}$ and other loci have not been performed, as far as we know. A field experiment was conducted for $\mathrm{L}$ and $\mathrm{E}$ in the present study. Besides yield, yield components and other traits such as culm length and sink size were measured. On the basis of the data obtained, the effects of $E x(\mathrm{t})$ on yielding ability was examined.

\section{MATERIALS AND METHODS}

\section{Pair of isogenic lines}

The isogenic-line pair of $\mathrm{L}$ and $\mathrm{E}$ was used in the present study. This isogenic-line pair was developed from descendents of the $\mathrm{F}_{1}$ from Suweon $258 \times 36 \mathrm{U}$. The maternal parent Suweon 258 is an indica-type semi-dwarf variety which had been developed by the cooperation between Korea and International Rice Research Institute (IRRI 1980). The paternal line 36U was developed after 15 backcrosses by IR36 for the $\mathrm{F}_{1}$ of IR36 $\times \mathrm{N}-55$ (Url-carrying line) (Murai unpublished). IR 36 is a typical improved indica variety developed at International Rice Research Institute (Khush and Virk 2005). IR36 is a semi-dwarf variety carrying $s d l-d$ which had been broadly grown in Southeast Asia during 1980s (Imbe 2002). The 
heading-time characteristic of 36U is almost same as that of IR36. IR36 is an early-maturing variety in the tropics and subtropics (Khush and Virk 2005); nevertheless, it and Suweon 258 can be regarded as middle-heading in Kochi prefecture, Japan (Trieu et al 2010).

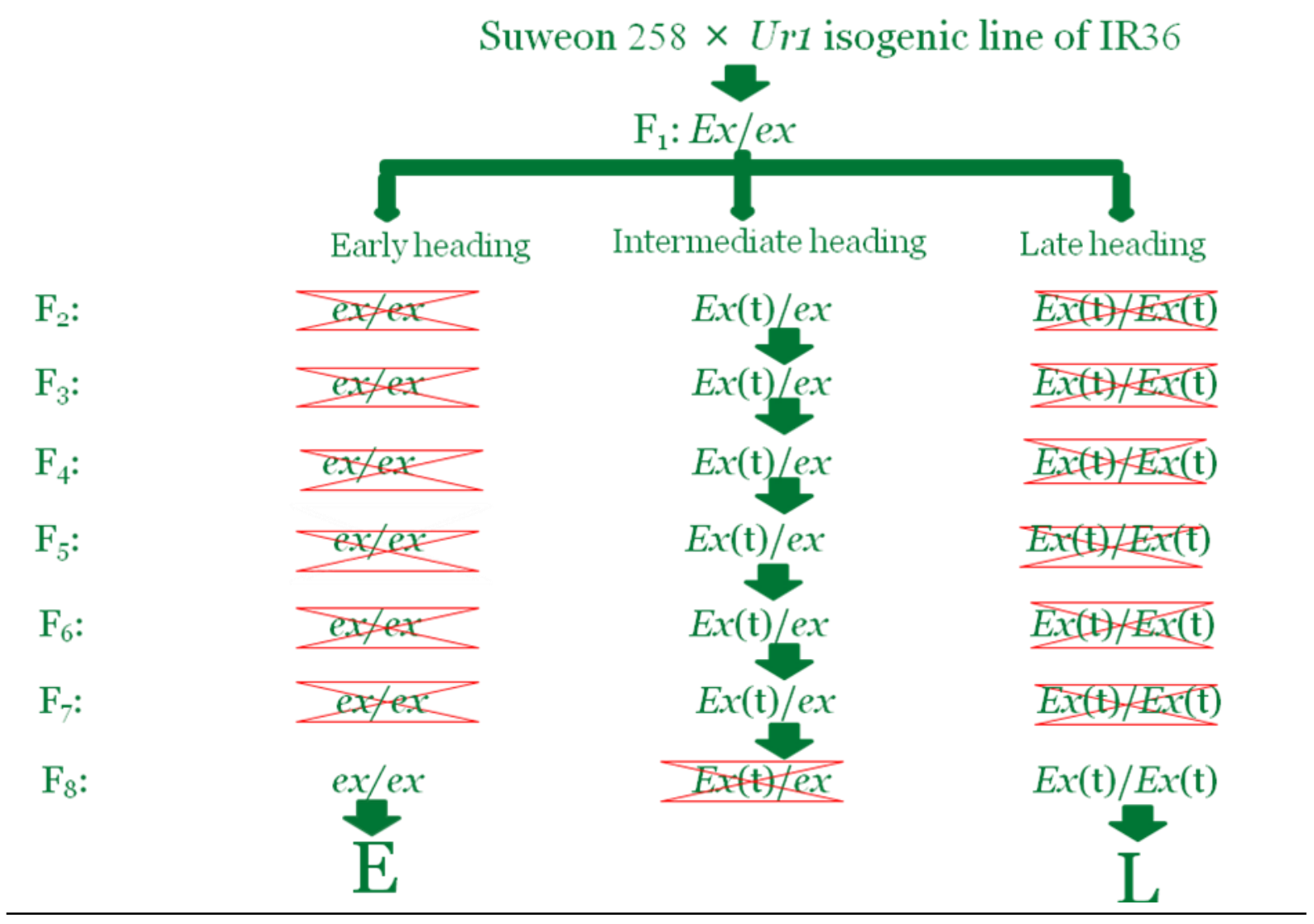

Figure 1. Procedure of developing early and late isogenic-line pair of $E$ and $L$, from the initial cross to establishment.

: not selected for later generations.

Figure 1 shows the developing process of a pair of early and late isogenic-lines, E and L. Suweon 258 was crossed with $36 \mathrm{U}$. Comparatively early-heading, late-heading and intermediate-heading plants were segregated in the $F_{2}$ population from the $F_{1}$. Early-heading, late-heading and intermediate-heading plants appeared in the $F_{3}$ population from an intermediate-heading plant of $F_{2}$. Similarly, in $F_{4}$ and later generations, plants with the three classes of heading appeared in a progeny population from an intermediate-heading plant of the previous generation. In the $\mathrm{F}_{8}$ population from an intermediate-heading $\mathrm{F}_{7}$ plant, a late-heading plant and an early-heading plant were selected for developing $\mathrm{L}$ and $\mathrm{E}$, respectively (Trieu et al 2010). Any genic segregation regarding heading time, culm length and other traits within $\mathrm{L}$ as well as $\mathrm{E}$ were not observed from $\mathrm{F}_{9}$ generation and thereafter. From the results of genetic analyses by using L, E, Suweon 258 and 36U, and descendents of mutual crosses among them, it is suggested that $E x(\mathrm{t})$ is an incompletely dominant allele controlling photosensitivity over its recessive allele $e x$, and the former and latter alleles are harbored in $\mathrm{L}$ and $\mathrm{E}$, respectively (Murai unpublished). 36U has ex/ex genotype (Trieu et al 2010). Suweon 258 harbors not only $E x(\mathrm{t})$ but also an inhibitor gene for it, resulting in the behavior of the middle heading in Kochi prefecture.

\section{Cultivation and fertilization in the experimental field}

Seeds were sterilized with a 1000-time solution of Benomyl ${ }^{\circledR}$ (benzimidazol) in 2011. In 2014, seeds were soaked with hot water of 62 to $55^{\circ} \mathrm{C}$ for 15 minutes for sterilization, particularly countermeasure for bacterial panicle blight and/or grain rot. The seeds were sown on plastic trays filled with granulated soil containing $\mathrm{N}, \mathrm{P}_{2} \mathrm{O}_{5}$ and $\mathrm{K}_{2} \mathrm{O}$ and being adjusted at $\mathrm{pH} 4.5$, on 2nd May in 2011 and 21st April in 
2014. Seedlings were grown at $25^{\circ} \mathrm{C}$ for the first five days and $21^{\circ} \mathrm{C}$ for the subsequent seven days in a natural-light type growth chamber in both years. Twelve-day old seedlings were transplanted at a spacing of $30 \mathrm{~cm} \times 15 \mathrm{~cm}\left(22.2\right.$ hills $\left./ \mathrm{m}^{2}\right)$ with two seedlings per hill to an experimental field of the Faculty of Agriculture (present name: Faculty of Agriculture and Marine Science), Kochi University $\left(\right.$ Nankoku $\left.33^{\circ} 33^{\prime} \mathrm{N}\right)$. Yield test was performed with three replications for the two lines in each of the two years. Each plot comprised 29 hills $\times 5$ rows (145 hills).

Table 1. Chemical fertilizers applied in the experimental field in 2011 and 2014

\begin{tabular}{|c|c|c|c|c|c|c|}
\hline Year & $\begin{array}{c}\text { Fertilizer } \\
\text { level }\end{array}$ & $\begin{array}{l}\text { Basal or } \\
\text { top-dressing }\end{array}$ & Chemical fertilizers applied & $\begin{array}{c}\mathbf{N} \\
\left(\mathrm{g} / \mathrm{m}^{2}\right)\end{array}$ & $\begin{array}{c}\mathrm{P}_{2} \mathrm{O}_{5} \\
\left(\mathrm{~g} / \mathrm{m}^{2}\right)\end{array}$ & $\begin{array}{r}\mathbf{K}_{2} \mathbf{O} \\
\left(\mathbf{g} / \mathbf{m}^{2}\right)\end{array}$ \\
\hline \multirow[t]{3}{*}{2011} & \multirow[t]{3}{*}{ N17 } & Basal & Ordinary chemical fertilizer & 5.00 & 5.00 & 5.00 \\
\hline & & Top-dressing & ECOLONG $^{\circledR} 413-140$ type & 12.00 & 12.00 & 12.00 \\
\hline & & & Total & 17.00 & 17.00 & 17.00 \\
\hline \multirow[t]{11}{*}{2014} & \multirow[t]{4}{*}{ N18 } & Basal & Ordinary chemical fertilizer & 1.33 & 1.33 & 1.33 \\
\hline & & Additional basal & ECOLONG $^{\circledR} 424-100$ type & 4.67 & 4.67 & 4.67 \\
\hline & & Top-dressing & ECOLONG $^{\circledR} 413-180$ type & 12.00 & 9.43 & 11.14 \\
\hline & & & Total & 18.00 & 15.43 & 17.14 \\
\hline & \multirow[t]{4}{*}{ N9 } & Basal & Ordinary chemical fertilizer & 1.33 & 1.33 & 1.33 \\
\hline & & Additional basal & ECOLONG $^{\circledR} 424-100$ type & 1.67 & 1.67 & 1.67 \\
\hline & & Top-dressing & ECOLONG $^{\circledR} 413-180$ type & 6.00 & 4.71 & 5.57 \\
\hline & & & Total & 9.00 & 7.71 & 8.57 \\
\hline & \multirow[t]{3}{*}{$\mathrm{N} 4$} & Basal & Ordinary chemical fertilizer & 1.33 & 1.33 & 1.33 \\
\hline & & Top-dressing & ECOLONG $^{\oplus} 413-180$ type & 2.67 & 2.10 & 2.48 \\
\hline & & & Total & 4.00 & 3.43 & 3.81 \\
\hline
\end{tabular}

ECOLONG ${ }^{\circledR} 424-100$ type, ECOLONG ${ }^{\circledR} 424-140$ type and $E C O L O N G^{\circledR} 413-180$ type: see text.

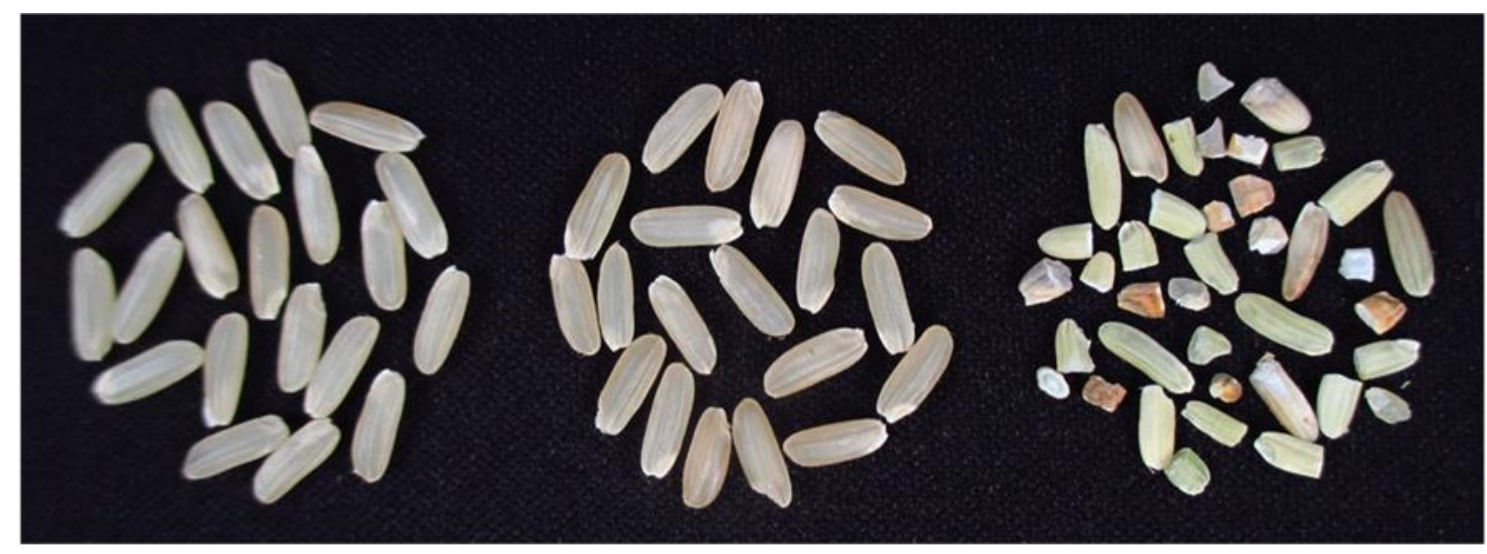

Thickness $\geq 1.7 \mathrm{~mm} \quad 1.7 \mathrm{~mm}>$ Thickness $\geq 1.5 \mathrm{~mm} \quad 1.5 \mathrm{~mm}>$ Thickness

Figure 2. Classification of brown rice by thickness in $\mathrm{L}$.

In 2011, just before ploughing, an ordinary chemical fertilizer, manufactured by Central Chemical Co., Ltd., Tokyo, Japan, containing $\mathrm{N}, \mathrm{P}_{2} \mathrm{O}_{5}$ and $\mathrm{K}_{2} \mathrm{O}$ was applied as basal dressing at the rate of $5.00 \mathrm{~g} / \mathrm{m}^{2}$ for each of $\mathrm{N}, \mathrm{P}_{2} \mathrm{O}_{5}$ and $\mathrm{K}_{2} \mathrm{O}$ (Table 1). Top-dressing was performed 54 days or 59 days before 80\%-heading for $\mathrm{L}$ and $\mathrm{E}$ with a slow release and coated fertilizer ECOLONG ${ }^{\circledR} 424-140$ type (about 5\% of each nutrient element is readily available) containing $\mathrm{N}, \mathrm{P}_{2} \mathrm{O}_{5}$ and $\mathrm{K}_{2} \mathrm{O}$ at the rate of 14,14 and $14 \%$, respectively, manufactured by JCAM AGRI Co., Ltd. at the rate of $12.00 \mathrm{~g} / \mathrm{m}^{2}$ of each of the three nutrient elements. Chemical fertilizers containing $\mathrm{N}, \mathrm{P}_{2} \mathrm{O}_{5}$ and $\mathrm{K}_{2} \mathrm{O}$ were applied by both basal and top dressings at the nitrogen levels of $4.00,9.00$ and $18.00 \mathrm{~g} / \mathrm{m}^{2}$ in total in 2014 , which were denoted by "N4", "N9" and "N18", respectively. Just before ploughing, the ordinary chemical fertilizer containing $\mathrm{N}, \mathrm{P}_{2} \mathrm{O}_{5}$ and $\mathrm{K}_{2} \mathrm{O}$ was applied as basal dressing at the rate of $1.33 \mathrm{~g} / \mathrm{m}^{2}$ for each of the three nutrient elements on April 10, 2014 (Table 1). Additional basal application was performed at the rate of 4.67 
$\mathrm{g} / \mathrm{m}^{2}$ and $1.67 \mathrm{~g} / \mathrm{m}^{2}$ of each of $\mathrm{N}, \mathrm{P}_{2} \mathrm{O}_{5}$, and $\mathrm{K}_{2} \mathrm{O}$ for $\mathrm{N} 18$ and $\mathrm{N} 9$, respectively, with a slow release and coated fertilizer ECOLONG ${ }^{\circledR} 424-100$ type (about $7 \%$ of each nutrient element is readily available) manufactured by JCAM AGRI Co., Ltd. four days after transplanting. Hence, the totals of the basal application were $6.00 \mathrm{~g} / \mathrm{m}^{2}, 3.00 \mathrm{~g} / \mathrm{m}^{2}$, and $1.33 \mathrm{~g} / \mathrm{m}^{2}$ for each of $\mathrm{N}, \mathrm{P}_{2} \mathrm{O}_{5}$ and $\mathrm{K}_{2} \mathrm{O}$ in $\mathrm{N} 18, \mathrm{~N} 9$ and $\mathrm{N} 4$, respectively (Table 1). Moreover, top-dressing was performed 63 days or 64 days before $80 \%$-heading (after 75 and 61 days after transplanting) for $\mathrm{L}$ and $\mathrm{E}$ with another slow release and coated fertilizer ECOLONG ${ }^{\circledR} 413-180$ type (about $3 \%$ of each nutrient element is readily available) containing $\mathrm{N}, \mathrm{P}_{2} \mathrm{O}_{5}$ and $\mathrm{K}_{2} \mathrm{O}$ at the rate of 14,11 and $13 \%$, respectively, manufactured by the company mentioned above. Accordingly, 12.00, 6.00 and $2.67 \mathrm{~g} / \mathrm{m}^{2}$ of nitrogen were top-dressed for $\mathrm{N} 18$, N9 and N4, respectively. The total amounts of $\mathrm{N}, \mathrm{P}_{2} \mathrm{O}_{5}$ and $\mathrm{K}_{2} \mathrm{O}$ (basal application + top-dressing) for the three fertilizer levels were summarized in Table 1. Experiment for $\mathrm{L}$ and $\mathrm{E}$ in the three fertilizer levels was conducted by randomized block design with three replications in 2014.

\section{Measurements of total dry matter and leaf area}

At each of $80 \%$-heading stage and maturity, panicle number per hill was counted for nine hills per plot at south, middle and north parts of the second row in the three plots of the first to third replications, respectively, in each of $\mathrm{L}$ and $\mathrm{E}$ in 2011. Five hills, which had intermediate panicle numbers, were sampled from the nine hills of each plot at each stage. Dry weight excluding roots of each hill was measured after oven drying at $75^{\circ} \mathrm{C}$ for two days. The total area of living leaves in each hill was measured using Automatic area meter AAM-8 manufactured by Hayashi Denko Co., Ltd., Tokyo, Japan at $80 \%$-heading stage and maturity. Total dry matter weight per $\mathrm{m}^{2}$ and leaf area index (LAI) was calculated from the measured values. However, yield and yield components were not measured, because the grain yield of $\mathrm{L}$ was seriously damaged by infection of bacterial panicle blight (grain rot) in 2011.

\section{Measurements of yield, yield components and related traits}

Yield, yield components, and other traits were measured in 2014 by the following procedure: all panicles of 25 hills were sampled from the 3rd to 27 th hill of the 4th row of each plot at maturity and dried in hot air ovens with a temperature ranging from 30 to $45^{\circ} \mathrm{C}$ for 20 hours to 30 hours until the average moisture content of rough rice lowered to $11 \%$ or less. The panicle weight of each hill was measured after cutting at $1.5 \mathrm{~mm}$ below panicle bases.

Out of nine hills randomly selected from 25 hills of each plot, five hills having intermediate panicle weights were selected. The panicles of the five hills were threshed, and all spikelets in each hill were counted. Each spikelet was dehulled and examined for endosperm development as described by Murai et al (2005): a spikelet containing any developed endosperm containing starch was regarded as fertilized. The number of fertilized spikelets was counted on a hill basis. Grains after hulling (hereafter "grains") were sieved by both $1.7 \mathrm{~mm}$ and $1.5 \mathrm{~mm}$ sieves to separate grains into three ranks by thickness: above $1.7 \mathrm{~mm}$, from 1.5 to $1.7 \mathrm{~mm}$, and below $1.5 \mathrm{~mm}$. Grains in each rank were separately counted and weighed in each of the five hills. The number of grains below $1.5 \mathrm{~mm}$ was estimated by subtracting the number of grains above $1.5 \mathrm{~mm}$ from the fertilized spikelets in each hill. The percentage of grain weight of each of the three ranks to panicle weight was calculated in the five selected hills of each plot; then, the grain weight of each rank of 25 hills of each plot was estimated from these three percentages. The moisture content (\%) of grains above $1.7 \mathrm{~mm}$ in each plot was measured, and the grain weight at $15 \%$ moisture was estimated. For japonica rice in Japan, brown rice just after hulling is separated with $1.7 \mathrm{~mm}$-sieve or a wider one to select brown-rice grains with sufficiently high quality for milling from grains with lower quality. However, both in $\mathrm{L}$ and $\mathrm{E}$, grains with thickness from 1.5 to $1.7 \mathrm{~mm}$ can be regarded as possessing quality sufficient for milling (Figure 2). Accordingly, we included the grains from 1.5 to $1.7 \mathrm{~mm}$ thickness into ripened grains.

\section{RESULTS}

Number of days to Heading

As shown in Table 2, 80\%-heading dates of $\mathrm{L}$ and $\mathrm{E}$ were 27th and 8th of August, respectively, in 2011. In 2014, that of L was 24th August at all of the fertilizer levels, while that of E was 5th August at N9, 
and 6th August at both N18 and N4. The numbers of days to 80\%-heading from sowing in L were 117 and 125 days, respectively, in 2011 and 2014, and those of E was 98 days, and 106 or 107 days, respectively, in both years. Hence, $\mathrm{L}$ was 18 or 19 days later in $80 \%$-heading than $\mathrm{E}$ in both years.

Table 2. Dates of $80 \%$-heading and heading durations in $\mathrm{L}$ and $\mathrm{E}$

\begin{tabular}{llcccc}
\hline Year & Traits & Fertilizer level & L & E & Difference \\
\hline 2011 & Date of 80\%-heading & & Aug. 27 & Aug. 8 & \\
\cline { 2 - 5 } & Number of days to 80\%-heading from sowing & & 117 & 98 & 19 \\
\hline \multirow{2}{*}{2014} & Date of 80\%-heading & N18 & Aug. 24 & Aug. 6 & \\
\cline { 2 - 6 } & & N9 & Aug. 24 & Aug. 5 \\
\cline { 2 - 6 } & & N4 & Aug. 24 & Aug. 6 & \\
\cline { 2 - 6 } & Number of days to 80\%-heading from sowing & N18 & 125 & 107 & 18 \\
\cline { 2 - 6 } & & N9 & 125 & 106 & 19 \\
\hline
\end{tabular}

Table 3. Total dry matter, LAI and panicles $/ \mathrm{m}^{2}$ in $\mathrm{L}$ and $\mathrm{E}$ in 2011

\begin{tabular}{llrr}
\hline Stage of growth & Traits & L & E \\
\hline $80 \%$-heading & Total dry matter $\left(\mathrm{g} / \mathrm{m}^{2}\right)$ & 1402 & 1096 \\
\cline { 2 - 4 } Maturity & LAI & 4.5 & 4.3 \\
\hline & Total dry matter $\left(\mathrm{g} / \mathrm{m}^{2}\right)$ & 1672 & 1562 \\
\cline { 2 - 4 } & LAI & $0.8 *$ & 1.9 \\
\cline { 2 - 4 } & Panicles $/ \mathrm{m}^{2}$ & 276 & 296 \\
\hline
\end{tabular}

* Significantly different between $L$ and $E$ at the $5 \%$ level.

Total Dry matter and LAI at $80 \%$-heading and maturity

In 2011 , L was higher by $306 \mathrm{~g} / \mathrm{m}^{2}$ in total dry matter weight at $80 \%$-heading than $\mathrm{E}$, and the former was $110 \mathrm{~g} / \mathrm{m}^{2}$ higher in that at maturity than the latter, although being not statistically significant (Table 3). $\mathrm{L}$ was not significantly different from $\mathrm{E}$ in LAI at $80 \%$-heading, while $\mathrm{L}$ was lower than $\mathrm{E}$ in that at maturity. Regarding the panicle number per $\mathrm{m}^{2}$ at maturity, $\mathrm{L}$ was not significantly different from $\mathrm{E}$.

Table 4. Analysis of variance for yield and its components at the three fertilizer levels in $L$ and $E$ In 2014. Numerals in the table show F-values.

\begin{tabular}{|c|c|c|c|c|c|}
\hline \multirow{2}{*}{ Traits } & \multicolumn{5}{|c|}{ Source of variation } \\
\hline & Latenessgen & e (A) & Fertilizer le & vel (B) & Interaction $(A \times B)$ \\
\hline Total brown rice yield $\left(\mathrm{g} / \mathrm{m}^{2}\right)$ & 26.23 & $* *$ & 6.72 & $*$ & $<1$ \\
\hline Yield-1.5mm sieve $\left(\mathrm{g} / \mathrm{m}^{2}\right)$ & 20.00 & ** & 8.50 & ** & $<1$ \\
\hline Spikelets / panicle & 176.12 & *** & $<1$ & & 1.17 \\
\hline Panicles $/ \mathrm{m}^{2}$ & 4.91 & & 18.47 & $* *$ & $<1$ \\
\hline 1000 -grain weight $1.5 \mathrm{~mm}$-sieve $(\mathrm{g})$ & 13.67 & ** & 1.11 & & $<1$ \\
\hline
\end{tabular}

\section{Yield and yield components}

Table 4 shows the results of the analysis of variance for yield and yield components except for the percentage of ripened grains in the three fertilizer levels in L and E. Effects of the lateness gene and fertilizer level were statistically significant in total brown rice yield and yield $-1.5 \mathrm{~mm}$ sieve, but the interactive effect between them was not significant. Regarding spikelet number per panicle and 1000-grain weight, the effect of $E x(t)$ was significant, but the effects of fertilizer level and the interaction were not significant. In panicle number per $\mathrm{m}^{2}$, the effect of the fertilizer level was significant but the effects of the lateness gene and the interaction were not significant.

The number of grains from 1.5 to $1.7 \mathrm{~mm}$ thickness accounted for 10.3 to $11.6 \%$ and 9.0 to $10.0 \%$ of all fertilized grains in the three fertilizer levels in L and E, respectively (Table 5-(1)). Grain weight from 1.5 to $1.7 \mathrm{~mm}$ thickness accounted for 9.5 to $11.1 \%$ and 8.0 to $9.1 \%$ of all fertilized-grain weight in the three fertilizer levels in L and E, respectively (Table 5-(2)). The total grain weight above $1.5 \mathrm{~mm}$ thickness was denoted by "yield-1.5mm sieve". Furthermore, "total brown rice yield" was the brown 
rice weight of all fertilized spikelets. Ripened-grain percentage was the ratio (\%) of the number of ripened grains to the total number of spikelets. The average spikelet number per hill of the 25 hills in each plot was estimated from that of the five hills and the ratio of the average panicle weight of the 25 hills to that of the five hills. Sink size (single grain weight $\times$ spikelet number per $\mathrm{m}^{2}$ ) was estimated.

Regarding total brown rice yield including all grains with thicknesses above and below $1.5 \mathrm{~mm}$, L was higher by 58,58 and $89 \mathrm{~g} / \mathrm{m}^{2}$, respectively, than E at N18, N9, and N4 (Table 6). Hence, $E x(\mathrm{t})$ increased this trait by 10 to $18 \%$. Regarding yield- $1.5 \mathrm{~mm}$ sieve, L was 597,575 and $545 \mathrm{~g} / \mathrm{m}^{2}$ at N18, N9 and N4, respectively, which correspond 109,110 and $115 \%$ to those of E. Regarding fertilizer response from N4 to N18, total brown rice yield was increased by 45 and $76 \mathrm{~g} / \mathrm{m}^{2}$, respectively, in L and $\mathrm{E}$, and yield $-1.5 \mathrm{~mm}$ sieve was increased by 52 and $72 \mathrm{~g} / \mathrm{m}^{2}$ in the former and later, even though the lateness gene $\times$ fertilizer level interaction was not significantly effective. Spikelet number per panicle was 129.0 to 129.9 in $\mathrm{L}$ and 106.2 to 111.2 in E, showing that $E x(\mathrm{t})$ increased this trait by 16 to $22 \%$ in the three fertilizer levels. Ex(t) decreased 1000-grain weight by 2 to $4 \%$ in the three fertilizer levels.

Table 5. Classification of grains by thickness at each of the three fertilizer level in $L$ and $E$ (1) Percentage on the basis of grain number

\begin{tabular}{|c|c|c|c|c|c|c|}
\hline Traits & Fertilizer level & $\mathbf{L}$ & & $\mathbf{E}$ & & LSD (0.05) \\
\hline \multirow[t]{3}{*}{ Yield $>1.7 \mathrm{~mm}$ sieve } & N18 & 66.6 & $\mathrm{~b}$ & 70.6 & ab & \multirow[t]{3}{*}{4.9} \\
\hline & N9 & 70.6 & $\mathrm{ab}$ & 73.3 & $\mathrm{a}$ & \\
\hline & N4 & 69.6 & $\mathrm{ab}$ & 72.0 & $\mathrm{a}$ & \\
\hline \multirow[t]{3}{*}{ Yield $1.5-1.7 \mathrm{~mm}$ sieve } & N18 & 11.6 & a & 9.4 & $\mathrm{a}$ & \multirow[t]{3}{*}{3.4} \\
\hline & N9 & 11.0 & $\mathrm{a}$ & 9.0 & $\mathrm{a}$ & \\
\hline & N4 & 10.3 & a & 10.0 & $\mathrm{a}$ & \\
\hline \multirow[t]{3}{*}{ Yield $<1.5 \mathrm{~mm}$ sieve } & N18 & 21.7 & a & 20.0 & a & \multirow[t]{3}{*}{4.4} \\
\hline & N9 & 18.4 & a & 17.7 & $\mathrm{a}$ & \\
\hline & N4 & 20.1 & $\mathrm{a}$ & 18.0 & $\mathrm{a}$ & \\
\hline
\end{tabular}

(2) Percentages on the basis of grain weight

\begin{tabular}{|c|c|c|c|c|c|c|}
\hline Traits & Fertilizer level & $\mathbf{L}$ & & $\mathbf{E}$ & & LSD (0.05) \\
\hline \multirow[t]{3}{*}{ Yield $>1.7 \mathrm{~mm}$ sieve } & N18 & 83.0 & $\mathrm{a}$ & 86.5 & $\mathrm{a}$ & \multirow[t]{3}{*}{4.9} \\
\hline & N9 & 84.6 & $\mathrm{a}$ & 87.7 & a & \\
\hline & N4 & 83.0 & $\mathrm{a}$ & 85.8 & $\mathrm{a}$ & \\
\hline \multirow[t]{3}{*}{ Yield $1.5-1.7 \mathrm{~mm}$ sieve } & N18 & 11.1 & a & 8.6 & a & \multirow[t]{3}{*}{3.5} \\
\hline & N9 & 10.2 & a & 8.0 & a & \\
\hline & N4 & 9.5 & $\mathrm{a}$ & 9.1 & $\mathrm{a}$ & \\
\hline \multirow[t]{3}{*}{ Yield $<1.5 \mathrm{~mm}$ sieve } & N18 & 6.0 & a & 4.9 & a & \multirow[t]{3}{*}{3.3} \\
\hline & N9 & 5.2 & a & 4.2 & a & \\
\hline & N4 & 7.5 & $\mathrm{a}$ & 5.1 & $\mathrm{a}$ & \\
\hline
\end{tabular}

Values followed by the same letter within each rank by grain thickness are not significantly different at the 5\% level, determined by LSDs in the table. Analysis of variance was conducted for percentage data of all combinations of the fertilizer levels and lines in each rank by grain thickness (\%).

Panicle number per $\mathrm{m}^{2}$ was not significantly different between $\mathrm{L}$ and $\mathrm{E}$ at every fertilizer level. From $\mathrm{N} 4$ to N18, this trait was increased by 43 and 38, respectively, in L and E. In L and E, the positive fertilizer response in total brown rice yield as well as in yield $-1.5 \mathrm{~mm}$ sieve is considered to be caused by that in panicle number per $\mathrm{m}^{2}$, because significant fertilizer response was not noticed in spikelet number per panicle.

Table 6. Yield and its components at the three fertilizer levels in $L$ and $E$ in 2014

\begin{tabular}{|c|c|c|c|c|c|c|c|}
\hline Traits & Fertilizer level & I & & & $\mathbf{E}$ & & $\begin{array}{c}\text { LSD } \\
(0.05)\end{array}$ \\
\hline \multirow[t]{3}{*}{ Total brown rice yield $\left(\mathrm{g} / \mathrm{m}^{2}\right)$} & N18 & 635 & $\mathrm{a}$ & $(110)^{1}$ & 577 & bc & \multirow[t]{3}{*}{52} \\
\hline & N9 & 606 & $\mathrm{ab}$ & $(111)$ & 548 & $\mathrm{~cd}$ & \\
\hline & N4 & 590 & abc & (118) & 501 & $\mathrm{~d}$ & \\
\hline \multirow[t]{2}{*}{ Yield $-1.5 \mathrm{~mm}$ sieve $\left(\mathrm{g} / \mathrm{m}^{2}\right)$} & N18 & 597 & $\mathrm{a}$ & (109) & 548 & $\mathrm{bc}$ & \multirow[t]{2}{*}{48} \\
\hline & N9 & 575 & $\mathrm{ab}$ & $(110)$ & 525 & $\mathrm{c}$ & \\
\hline
\end{tabular}




\begin{tabular}{|c|c|c|c|c|c|c|c|}
\hline & N4 & 545 & bc & $(115)$ & 476 & d & \\
\hline \multirow[t]{3}{*}{ Spikelets/panicle } & N18 & 129.2 & $\mathrm{a}$ & (116) & 111.2 & $\mathrm{~b}$ & \multirow[t]{3}{*}{6.0} \\
\hline & N9 & 129.0 & $\mathrm{a}$ & $(118)$ & 109.2 & b & \\
\hline & $\mathrm{N} 4$ & 129.9 & $\mathrm{a}$ & $(122)$ & 106.2 & $\mathrm{~b}$ & \\
\hline \multirow[t]{3}{*}{ Panicles $/ \mathrm{m}^{2}$} & N18 & 338 & $\mathrm{a}$ & (98) & 344 & $\mathrm{a}$ & \multirow[t]{3}{*}{21} \\
\hline & N9 & 308 & $\mathrm{bc}$ & (94) & 327 & $\mathrm{ab}$ & \\
\hline & N4 & 295 & $\mathrm{c}$ & (97) & 306 & $\mathrm{bc}$ & \\
\hline \multirow{3}{*}{$\begin{array}{l}\text { 1000-grain weight } 1.5 \mathrm{~mm} \text {-sive } \\
(\mathrm{g})\end{array}$} & N18 & 20.6 & $\mathrm{bc}$ & (96) & 21.5 & $\mathrm{a}$ & \multirow[t]{3}{*}{0.7} \\
\hline & N9 & 20.6 & $\mathrm{bc}$ & $(97)$ & 21.3 & $a b$ & \\
\hline & N4 & 20.5 & $\mathrm{c}$ & (98) & 21.0 & $a b c$ & \\
\hline
\end{tabular}

${ }^{1}$ Percentage of $L$ to $E$.

Values followed by the same letter within each trait are not significantly different at the 5\% level, determined by LSDs in the table.

\section{Ripened-grain percentage and other traits}

As shown in Table 7, a statistically significant difference between L and E was not noticed for the ripened-grain percentage. The effects of fertilizer level and the interaction were not significant in this trait, as mentioned above.

Regarding spikelet number per $\mathrm{m}^{2}$, sink size, culm length and panicle length; both lateness gene and fertilizer level were significantly effective but the interaction between them was not significant. Increases from $\mathrm{E}$ to $\mathrm{L}$ in spikelet numbers per $\mathrm{m}^{2}$ were 5416, 3997 and 5859, respectively, at $\mathrm{N} 18$, N9 and N4 which corresponds to 18, 14 and 11\% (Table 8). Regarding fertilizer response from N4 to N18, this trait was increased by 5309 and 5752, respectively, in L and E. Ex(t) significantly increased sink size $\left(\mathrm{g} / \mathrm{m}^{2}\right)$ by 7 to $15 \%$ in $\mathrm{L}$ in the three fertilizer levels. From N4 to N18, sink size was increased by $114 \mathrm{~g} / \mathrm{m}^{2}$, in L, and by $141 \mathrm{~g} / \mathrm{m}^{2}$ in E. Ex(t) increased culm length and panicle length by 6 or $7 \%$ and 4 or $8 \%$, respectively, in the three fertilizer levels. Increases from N4 to N18 in culm length were $2.2 \mathrm{~cm}$ and $1.9 \mathrm{~cm}$ in $\mathrm{L}$ and $\mathrm{E}$, and that in panicle length was $1.8 \mathrm{~cm}$ and $0.9 \mathrm{~cm}$ in $\mathrm{L}$ and $\mathrm{E}$.

Table 7. Analysis of variance for ripened grain percentage and other traits at the three fertilizer levels in $L$ and $E$ in 2014. Numerals in the table show $F$-values.

\begin{tabular}{|c|c|c|c|c|c|}
\hline \multirow[b]{2}{*}{ Trait } & \multicolumn{5}{|c|}{ Source of variation } \\
\hline & \multicolumn{2}{|c|}{$\begin{array}{l}\text { Lateness gene } \\
\text { (A) }\end{array}$} & \multicolumn{2}{|c|}{$\begin{array}{l}\text { Fertilizer level } \\
\text { (B) }\end{array}$} & $\begin{array}{c}\text { Interaction } \\
(A \times B)\end{array}$ \\
\hline Ripened-grain percentage & $<1$ & & 3.76 & & $<1$ \\
\hline Spikelets $/ \mathrm{m}^{2}$ & 37.19 & $* *$ & 14.81 & $* *$ & $<1$ \\
\hline Sink size ${ }^{1}\left(\mathrm{~g} / \mathrm{m}^{2}\right)$ & 15.92 & $* *$ & 13.85 & $* *$ & $<1$ \\
\hline Culm length $(\mathrm{cm})$ & 128.76 & $* *$ & 9.93 & $* *$ & $<1$ \\
\hline Panicle length $(\mathrm{cm})$ & 20.57 & $* *$ & 9.19 & $* *$ & 1.36 \\
\hline \multicolumn{6}{|c|}{$\begin{array}{l}\text { Degrees of freedom for lateness gene, fertilizer level, and interaction are } 1,2 \text { and 2, respectively. Degrees of freedom fo } \\
\text { replication and error are } 2 \text { and } 10 \text {, although these items are abridged in the table. } \\
*, * * \text { Significant at the } 5 \% \text { and } 1 \% \text { levels, respectively. }\end{array}$} \\
\hline
\end{tabular}

Table 8. Ripened-grain percentage and other traits at the three fertilizer levels in $L$ and $E$ in 2014

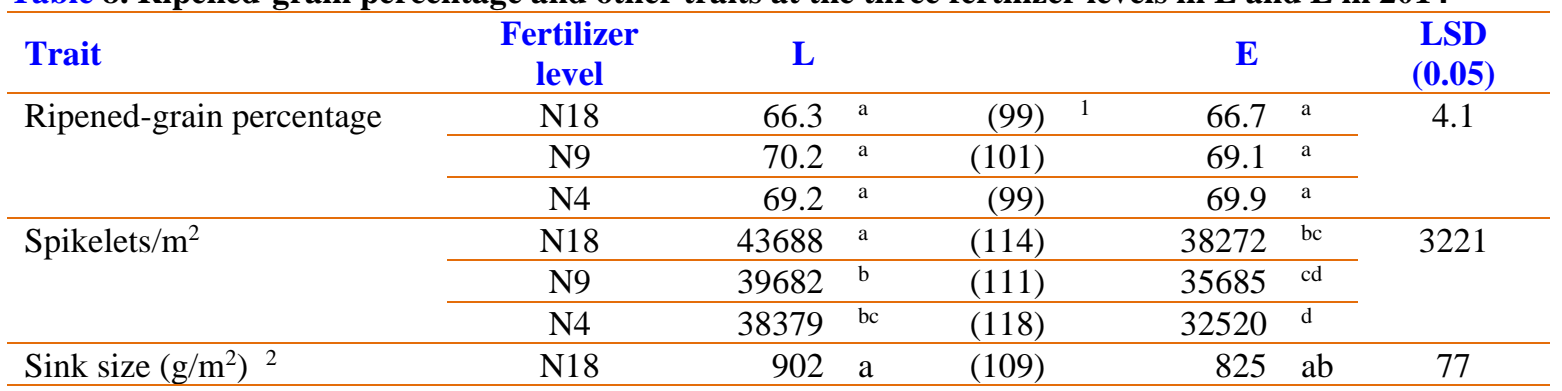




\begin{tabular}{|c|c|c|c|c|c|c|c|}
\hline & N9 & 819 & $\mathrm{~b}$ & (107) & 762 & $\mathrm{~b}$ & \\
\hline & N4 & 788 & $\mathrm{~b}$ & (115) & 684 & $\mathrm{c}$ & \\
\hline Culm length $(\mathrm{cm})$ & N18 & 71.9 & $\mathrm{a}$ & (107) & 67.2 & $\mathrm{c}$ & 1.5 \\
\hline & N9 & 70.2 & $\mathrm{~b}$ & (106) & 66.4 & cd & \\
\hline & N4 & 69.7 & $\mathrm{~b}$ & (107) & 65.3 & d & \\
\hline Panicle length $(\mathrm{cm})$ & N18 & 24.3 & a & (108) & 22.6 & $\mathrm{bc}$ & 1.0 \\
\hline & N9 & 23.2 & $\mathrm{~b}$ & (104) & 22.3 & $\mathrm{bc}$ & \\
\hline & N4 & 22.5 & $\mathrm{bc}$ & (104) & 21.7 & $\mathrm{c}$ & \\
\hline
\end{tabular}

Values followed by the same letter within each trait are not significantly different at the $5 \%$ level, determined by LSDs in the table.

${ }^{1}$ Percentage of L to E.

${ }^{2}$ single grain weight with $1.5 \mathrm{~mm}$-sieve $\times$ spikelets $/ \mathrm{m}^{2}$.

\section{DISCUSSION}

Lateness allele $E x(\mathrm{t})$ in L delayed heading by 18 or 19 days compared with its photo insensitive allele $e x$ in E. Statistically significant difference was not noticed between $\mathrm{L}$ and $\mathrm{E}$ for ripened-grain percentage and panicle number per $\mathrm{m}^{2}$ in each fertilizer level. Ex(t) decreased 1000-grain weight by 2 to $4 \%$. On the other hand, $E x(\mathrm{t})$ significantly increased total brown rice yield by 10 to $18 \%$, spikelet number per $\mathrm{m}^{2}$ by 11 to $18 \%$ and sink size by 7 to $15 \%$, by increasing spikelet number per panicle by 16 to $22 \%$. Hence, it is inferred that the effect of $E x(\mathrm{t})$ on yield was mainly due to its effect of increasing spikelet number per panicle. N18 is an outstandingly high fertilizer level in Japan. It is noteworthy that L $\left(635 \mathrm{~g} / \mathrm{m}^{2}\right)$ was $9 \%$ higher than E in yield-1.5mm sieve. IR36, a typical improved indica variety, occupied the widest cultivated area in Southeast Asia during 1980s (Imbe 2002). Suweon 258 achieved brown rice yield of about $1000 \mathrm{~g} / \mathrm{m}^{2}$ by heavy fertilizer-application in a field test in Kagawa Prefecture, a neighboring prefecture of Kochi (Komatsu et al 1984). L and E have typical plant type of improved indica variety with short culms and erect leaves, which are inherited from IR36 and Suweon 258. It is inferred that L and $\mathrm{E}$ are donated positive responsiveness to higher fertilizer application from Suweon 258. Late genotypes attain heading stages in late August or early September in the Kyushu region of Japan; and heading characteristic of $\mathrm{L}$ seems to be similar to those of them (Agriculture Production Bureau, Ministry of Agriculture, Forestry and Fisheries, Japan 1997). Sakai et al (2006) suggested that late varieties of the Kyushu region have the advantage to avoid high-temperature damage of grain filling because their maturing durations are mainly in September in which temperature is lower than in August ordinarily. Consequently, Ex(t) could be utilized to develop high yielding varieties for sufficiently warm districts in which late varieties can be cultivated.

\section{REFERENCES}

Agricultural Production Bureau, Ministry of Agriculture, Forestry and Fisheries, Japan. 1997. Characteristics of rice varieties recommended by the prefectures of Japan. In: Characteristics of rice, wheat and barley varieties recommended in Japan. Association of Advancement of Agricultural Science, Tokyo. pp. 136-153 (in Japanese).

Akimoto S and Y Togari. 1939. Varietal differences in panicle development of rice with reference to early and late transplanting. Proc. Crop. Sci. Soc. Japan 11:168-184. https://www.jstage.jst.go.jp/article/jcs1927/11/1/11_1_168/_pdf/-char/en

Chang TT, BS Vergara and CC Li. 1969. Component analysis of duration from seeding to heading in rice by the basic vegetative phase and photoperiod sensitive phase. Euphytica 18:79-91. https://link.springer.com/content/pdf/10.1007\%2FBF00021985.pdf

Ebana K, T Shibaya, J Wu, K Matsubara, H Kanamori et al. 2011. Uncovering of major genetic factors generating naturally occurring variaiion in heading date among Asian rice cultivars. Theor. Appl. Genet. 122: 1199-1210. DOI: http://10.1007/s00122-010-1524-1

Ichitani K, Y Okumoto, T Tanisaka. 1997. Photoperiod sensitivity gene of Se-1 locus found in photoperiod insensitive rice cultivars of the northern limit region of rice cultivation. Breed. Sci. 47:145-152. DOI: https://doi.org/10.1270/jsbbs1951.47.145

Ichitani K, Y Okumoto and T Tanisaka. 1998. Genetic analysis of the rice cultivar Kasalath with special reference to two photoperiod sensitivity loci, E1 and Se1. Breed. Sci. 48: 51-57.

DOI: https://doi.org/10.1270/jsbbs1951.48.51 
Imbe T. 2002. Rice breeding in the tropical Asia - one of the aspects. In: overseas Trends in Crop Science and Mutation Breeding. Proceedings of Gamma Field Symposia, No. 41, July 17-18, 2002, Institute of Radiation Breeding, Ibaraki, Japan, pp.21-30. http://www.naro.affrc.go.jp/archive/nias/newsletter/gfs/pdf/041.pdf

IRRI. 1985. Parentage of IRRI crosses IR1 - IR30,000. The International Rice Research Institute, PO Box 933 , Manila, Phillipines.

Kawano K and A Tanaka.1968. Growth duration in relation to yield and nitrogen response in the rice plant. Japan. J. Breed. 18:46-52. DOI: 10.1270 / jsbbs 1951.18 .46

Khun LH, K Motomura, S Murayama, S Adania, A Nose. 2005. Linkage analysis of a lateness gene ef4 in rice, Oryza sativa L. Breed Sci. 55:231-235. https://www.jstage.jst.go.jp/article/jsbbs/55/2/55_2_231/_article/-char/ja/

Khush GS and PS Virk. 2005. IR varieties and their impact. The International Rice Research Institute, Los Banos (Philippines). p.75. http://books.irri.org/9712202062_content.pdf

Komatsu Y, T Kon, K Matuso, N Katayama and T Kataoka. 1984. Varietal characters of high-yielding foreign rice. Bull. Shikoku Agic. Exp. Stn. No. 43:1-37

Murai M, K Nakamura, M Saito, A Nagayama and K Ise. 2005. Yield-increasing Effect of a Major Gene, $U r 1$ (Undulate rachis -1) on Different Genetic Background in Rice. Breed. Sci. 55:279-285.

DOI: https://doi.org/10.1270/jsbbs.55.279

Okumoto Y, K Ichitani, H Inoue and T Tanisaka. 1996. Photoperiod insensitivity gene essential to the varieties grown in the northern limit region of paddy rice (Oryza sativa L.). Euphytica 92:63-66. https://link.springer.com/content/pdf/10.1007\%2FBF00022829.pdf

Okumoto Y, T Tanisaka and H Yamagata. 1991. A new tester line for analyzing heading time genes in rice. Rice Genet. Newsl. 8:129-131. https://archive.gramene.org/newsletters/rice_genetics/rgn8/v8tabocont.html

Saito H, Y Okumoto, T Teranishi, Y Qingbo, T Nakazaki and T Tanisaka. 2007. Heading time genes responsible for the regional adaptability of 'tongil-type short culmed rice cultivars' developed in Korea. Bred. Sci. 57:135-143. https://www.jstage.jst.go.jp/article/jsbbs/57/2/57_2_135/_article

Sakai M, M Okamoto, K Tamura, R Kaji, R Mizobuchi, H Hirabayashi, T Yagi, M Nishimura and S Fukaura. 2006. A new variety “Akimasari”. Bull. Natl. Agrc. Res. Cent. Kyushu Okinawa Reg. 47:43-62.

Terao H, Y Otani, Y Doi and S Idumi. 1942. Physiological studies of the rice plant with special reference to the crop failure caused by the occurrence of unseasonable low temperature. (VII) The effect of various low temperatures on the panicle differentiation, heading and ripening in the difference stages after transplanting to heading. Proc. Crop Sci. Soc. Japan 13:317-336.

Trieu T, S Malangen, S Dozaki, T Akaoka, Y Takemura, M Urabe and M Murai. 2010. Single-genic segregation in heading date, observed in a progeny ( $\mathrm{F}_{8}$ generation) of the cross between two indica-type varieties in rice. Shikoku J. Crop Sci. 47:44-45. DOI: http://10.13140/RG.2.1.4843.7281

Wada G and PCS Cruz. 1989. Varietal difference in nitrogen response of rice plant with special reference to growth duration. Jap. J. Crop Sci. 58:732-739. DOI: http://10.1626/jcs.58.732

Xue W, Y Xing, X Weng, Y Zhao, W Tang, L Wang, H Zhou, S Yu, C Xu, X Li and Q Zhang. 2008. Natural variation in $G h d 7$ is an important regulator of heading date and yield potential in rice. Nature 40(6): 761-767. DOI: http://10.1038/ng.143

Yokoo M and H Fujimaki. 1971. Tight linkage of blast resistance with late maturity observed in different indica varieties of rice. Jpn. J. Breed. 21:35-59. DOI: http://10.1270/jsbbs1951.21.35

Yokoo M and F Kikuchi.1977. Multiple allelism of the locus controlling heading time of rice, detected using close linkage with blast-resistance. Jpn. J. Breed. 21:123-130. DOI: http://10.1270/jsbbs1951.27.123

Yokoo M and F Kikuchi. 1982. Monogenic control of basic vegetative phase and photoperiod-sensitive phase in rice. Japan. J. Breed. 32:1-8 (in Japanese with English summary).

DOI: https://doi.org/10.1270/jsbbs1951.32.1

Yokoo M, F Kikuchi, A Nakane and H Fujimaki. 1980. Genetical analysis of heading time by aid of close linkage with blast resistance in rice. Bull. Natl. Inst. Agric. Sci. D31: 95-126, (in Japanese with English summary).

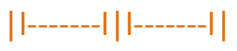

